\title{
Effect of $\beta$-Lactoglobulin A and B Whey Protein Variants on the Rennet-Induced Gelation of Skim Milk Gels in a Model Reconstituted Skim Milk System
}

\author{
M. A. Meza-Nieto, ${ }^{*}$ B. Vallejo-Cordoba, ${ }^{*}$ A. F. González-Córdova, ${ }^{*}$ L. Félix, $†$ and F. M. Goycoolea ${ }^{1}$ \\ *Laboratory of Dairy Science and Technology, and \\ †Laboratory of Biopolymers, Centro de Investigación en Alimentación y Desarrollo, AC (CIAD, AC), P.O. Box 1735 Hermosillo, \\ Sonora, 83000 Mexico
}

\begin{abstract}
The effect of fortifying reconstituted skim milk with increasing levels of the $\beta$-lactoglobulin ( $\beta$-LG) genetic variants $\mathrm{A}, \mathrm{B}$, and an $\mathrm{A}-\mathrm{B}$ mixture on rennet-induced gelation was studied by small deformation-sensitive rheology. Free-zone capillary electrophoresis and highsensitivity oscillatory rheology were used to elucidate the role of potential heterotypic associative interactions between whey proteins and casein in a mixed colloidal system, subjected to moderate heating $\left(65^{\circ} \mathrm{C}\right.$ for $\left.30 \mathrm{~min}\right)$ prior to renneting, on the gelling properties of the system. Increasing levels of added whey protein, in the concentration range of 0.225 to $1.35 \%$ of added protein, led to a concomitant progressive increase in the equilibrium shear storage modulus, $\mathrm{G}^{\prime}$ (recorded after $\sim 10,800$ $\mathrm{s})$, in the order $\beta$-LG B $>\beta$-LG A and $\beta$-LG A-B, as the general expected consequence of the setup of denser casein gel networks. The preferential effect of $\beta$-LG B over $\beta$-LG A on the mechanical strength of the gels may be due to the formation of cross-links and aggregates involving whey proteins and rennet hydrolysis products or an increase in the size of the casein micelle caused by the grafting of $\beta$-LG B to its surface, or both. The results of free-zone capillary electrophoresis were consistent with the notion that $\beta$-LG $\mathrm{B}$ (and not $\beta$-LG A) binds to the casein micelle under an optimal stoichiometry of $1: 0.045(\mathrm{mg} / \mathrm{mg})$, even in the absence of heat treatment. The liquid-like character of the gel networks formed, $\tan \delta$, was a parameter sensitive to the level of addition of $\beta$-LG A in particular. At low concentrations (up to $0.45 \%$ ) of $\beta$-LG A, $\tan \delta$ increased by almost twice as much, which was interpreted as a result of the increase in the loss modulus, $\mathrm{G}^{\prime \prime}$, of the sol fraction because of the presence of unbound $\beta$-LG A. At greater incremental concentrations of $\beta$-LG $(>0.45 \%)$, the formation of smaller whey protein aggregates confined to
\end{abstract}

Received April 19, 2006.

Accepted August 10, 2006.

${ }^{1}$ Corresponding author: fgoyco@cascabel.ciad.mx the sol fraction may have led to a progressive decrease in $\tan \delta$. The critical gel time, $t_{\text {gel }}$, was also affected by the concentration of added whey protein and described 3 zones of behavior, irrespective of the type of whey protein variant. The critical gel time was slightly shorter for $\beta$-LG B than for $\beta$-LG A at $0.45 \%$ of added whey protein, but this difference became larger at $0.67 \%$. Even when only $\beta$-LG B was found to associate with casein prior to renneting, both $\beta$-LG A and $\beta$-LG $\mathrm{B}$, either alone or mixed, had a profound influence on the mechanical strength and coagulation kinetics of the rennet-induced casein gels. This knowledge is expected to be useful to exert better control and optimize processing conditions during the manufacturing of cheese and cheese analogs.

Key words: $\beta$-lactoglobulin whey protein variant, rennet-induced gelation, capillary electrophoresis, rheology

\section{INTRODUCTION}

The major proteins in milk are of 2 general types, the disordered $\mathrm{CN}$ and the globular whey proteins. The predominant whey protein in bovine milk is $\beta$-LG, which comprises 7 to $12 \%$ of the total protein in milk (Euston et al., 1999). Bovine $\beta$-LG, a small dimeric globular protein, exists in a range of naturally occurring genetic variants that differ from each other by a few AA substitutions (Bikker et al., 2000). Two predominant genetic variants for $\beta$-LG protein are known, A (Gln59, Asp64, Val118) and B (Gln59, Gly64, Ala118). In Bos taurus breeds, $\mathrm{A}$ and $\mathrm{B}$ variants of $\beta$-LG predominate, whereas the $\mathrm{C}$ variant (His59, Gly64, Ala118) is far less frequent (Paterson et al., 1995). The AA substitutions between the different genetic variants of $\beta$-LG appear to have a small effect on the secondary and tertiary structures of the protein (Bewley et al., 1997). Although there are only small differences in the primary sequences and in the structural arrangements of the protein, the different genetic variants of $\beta$-LG have a marked effect on the physicochemical properties of the protein (Hill et al., 1996, 1997). 
The net negative charge of the monomer species is known to increase in the order $\beta$-LG $\mathrm{A}>\beta$-LG $\mathrm{B}>\beta$ LG C (Basch and Timasheff, 1967), and this is known to affect the pattern of aggregate formation during heat treatment (Brittan et al., 1997). These differences in aggregation behavior seem to have an effect on the association of whey protein with $\kappa$-CN during the acid gelation of heated milk (Bikker et al., 2000).

The functional properties of milk products can also be influenced by the genetic variants of $\beta$-LG. One of the main functional properties of whey proteins themselves is their ability to form viscoelastic gels when heated (Bikker et al., 2000). Bikker et al. (2000) studied the effect of fortifying reconstituted skim milk with different mixtures of whey proteins containing $\alpha$-LA and increasing concentrations of different genetic variants of $\beta$-LG (A, B, or $\mathrm{C}$ ) on the rheological properties of acid gels. They showed that the addition of $\beta$-LG A, $\beta$-LG B, $\beta$-LG C, or a mixture of $\beta$-LG A and B (A-B) whey proteins to milk prior to heat treatment influenced the mechanical properties of the gels.

In general, an increase in the storage modulus, $\mathrm{G}^{\prime}$, was observed in acid-induced milk gels as the level of whey protein increased (Bikker et al., 2000). The addition of whey protein variant $\mathrm{B}$ or $\mathrm{C}$ to the milk prior to heating and acidification clearly caused a progressive increase in $\mathrm{G}^{\prime}$ with increasing addition of protein. In contrast, whey protein variant A caused much smaller increases in $\mathrm{G}^{\prime}$, with protein levels of up to $0.7 \%$ (wt/ wt). Thus, the addition of whey protein variant $B$ or $C$ to milk prior to heat treatment provides larger aggregate structures that, on acidification, can lead to a greater extent of cross-linking and a firmer gel structure than the smaller aggregate structures formed during the heating of milk with added whey protein variant A (Lucey et al., 1997; Bikker et al., 2000).

The genetic variants of milk proteins have recently been of great interest in the dairy industry, in particular for their well-confirmed association with the composition, rennet coagulation, and cheese-making properties of milk, which are of economic importance for the cheese industry (Celik, 2003). The effect of $\beta$-LG whey protein variants on the coagulation properties of milk has been studied, although the results have been controversial. Ng-Kwai-Hang (1998) demonstrated that the phenotype $\mathrm{B}$ was associated with a longer rennet clotting time, a slower rate of firming, and a lower curd firmness (softer curd). Similarly, Marziali and NgKwai-Hang (1986) and Choi (1996) reported that the phenotype A gave the shortest clotting time and highest curd firmness. In contrast, other researchers (Aaltonen and Antila, 1987; Pagnacco and Caroli, 1987; Lodes et al., 1996; Celik, 2003) found no significant differences among the $\beta$-LG phenotypes. Yet Tong et al. (1993) suggested that milk containing $\beta$-LG B was more suited to cheese making because it produced a firmer rennet curd than that containing the A variants.

Thus, as Ng-Kwai-Hang (1998) suggested, differences in the technological properties of milk due to certain genetic variants need to be confirmed by studies comparing isolated and pure forms of the individual milk proteins without the confounding effects of other milk components. To our knowledge, no such studies have been conducted, in which the effects of the interaction of $\beta$-LG whey protein A and B variants on the rennet coagulation and rheological properties of skim milk have been addressed. Hence, the aim of this work was to investigate the effect of mixing isolated and purified $\beta$-LG A and B whey protein variants with $\mathrm{CN}$ in a model system. In addition, by including higher levels of whey protein content than those present in milk (approximately $0.30 \%$ ), some insight may be gained into the effect of $\beta$-LG variants on the coagulation properties of model systems resembling cheese analogs. To this end, capillary electrophoresis and sensitive oscillatory rheology were used as the main investigative techniques.

\section{MATERIALS AND METHODS}

\section{Reagents}

All reagents were of analytical grade, from Sigma Chemical Co. (St. Louis, MO); chymosin was from Chr. Hansen A/S (Hoersholm, Denmark). A batch of lowheat skim milk powder (whey protein nitrogen index of $7.64 \mathrm{mg} / \mathrm{g}$; $37.0 \%$ protein content on a dry weight basis) was used in all the experiments. Standards of $\beta$-LG A and B variants and $\alpha$-LA were from Sigma, and Milli$\mathrm{Q}$ water was used throughout unless otherwise stated.

\section{Milk Supply}

Fresh whole milk samples from homozygous Holstein cows with $\beta$-LG variants A or B were obtained directly from a dairy farm in Zamora, Sonora (Mexico). For the renneting experiments, skim milk powder was reconstituted to $10 \%(\mathrm{wt} / \mathrm{wt})$ total solids in water. The reconstituted skim milk samples were allowed to dissolve fully at room temperature $\left(\sim 25^{\circ} \mathrm{C}\right)$ under gentle magnetic stirring for $1 \mathrm{~h}$ before further treatment.

\section{Isolation and Purification of $\beta-L G$ and $\alpha-L A$}

Whole milk samples were heated to $40^{\circ} \mathrm{C}$ and skimmed by centrifugation. Casein was precipitated by acidification to $\mathrm{pH} 4.6$ with $4 \mathrm{~N} \mathrm{HCl}$, and the acid whey was freeze-dried and stored at $-20^{\circ} \mathrm{C}$ until used. Acid whey powder was reconstituted with water to $11 \%$ (wt/ 
wt) total solids and the corresponding $\beta$-LG variants and $\alpha$-LA were separated and purified using the low$\mathrm{pH}$ salt precipitation method as described by Mailliart and Ribadeau-Dumas (1988). Purified $\beta$-LG and $\alpha$-LA samples were freeze-dried and stored at $-20^{\circ} \mathrm{C}$.

\section{Preparation of Mixed CN-Whey Renneting Systems}

Milk powder solutions were made at $10 \%$ (wt/wt) and the necessary amounts of whey protein were added to yield $\beta$-LG concentrations of $0.15,0.30,0.45,0.60$, or $0.90 \%(\mathrm{wt} / \mathrm{wt})$ and $\alpha$-LA concentrations of $0.075,0.150$, $0.225,0.300$ or $0.450 \%$ (wt/wt; i.e., the $\alpha-\mathrm{LA}: \beta-\mathrm{LG}$ ratio was kept at 1:2) of $A, B$, or a mixture (1:1) of $A$ and $B$ variants, designated as $\beta$-LG A, $\beta$-LG $\mathrm{B}$, and $\beta$-LG A$\mathrm{B}$, respectively. Mixed systems $(\sim 5 \mathrm{~mL})$ were allowed to equilibrate to room temperature for $1 \mathrm{~h}$. The $\mathrm{pH}$ of the milk was adjusted to $\mathrm{pH} 6.6$ with $0.1 \mathrm{M} \mathrm{NaOH}$. To simulate pasteurization treatment, the samples were heated to $65^{\circ} \mathrm{C}$ for 30 min under continuous stirring in a thermostated water bath, cooled by immersion in ice water to below $10^{\circ} \mathrm{C}$, and held there for $2 \mathrm{~min}$. The samples were stirred for about $1 \mathrm{~h}$ until they reached $32^{\circ} \mathrm{C}$, and $1.7 \mathrm{~mL}$ was then loaded into the rheometer prior to adding an aliquot of $0.256 \mu \mathrm{L}$ of rennet.

\section{Capillary Electrophoresis}

Once separated, both $\beta$-LG A and B variants and $\alpha$ LA (Mailliart and Ribadeau-Dumas, 1988) were identified using the method described by Olguín-Arredondo and Vallejo-Córdoba (1999). This method was also used to measure quantitatively the amount of $\beta$-LG A and $\beta$-LG $\mathrm{B}$ that interacted with $\mathrm{CN}$ in skim milk after heating the model system. To this end, aliquot samples of the model mixtures used in the renneting experiments above containing varying amounts of $\beta$-LG A and $\mathrm{B}$ were analyzed using the same methodology.

\section{Sample Preparation for Capillary Electrophoresis}

Samples were prepared by $\mathrm{CN}$ precipitation at $\mathrm{pH}$ 4.6 with $4.5 \mathrm{~N} \mathrm{HCl}$, centrifugation, and filtration through $0.22-\mu \mathrm{m}$ nylon filters. Protein solutions of $\beta$ LG A or B analytical standards $(0.1,0.25,0.75,2.0$, and $3.0 \mathrm{mg} / \mathrm{mL}$ ) were prepared to construct the calibration curves used for quantitation. Protein standard solutions or filtered whey samples $(1 \mathrm{~mL})$ were diluted with 1 or $4 \mathrm{~mL}$ of borate buffer $(8.25 \mathrm{~m} M 0.1 \%$ Tween 20$)$ at $\mathrm{pH}$ 8.0, respectively. After dilution, protein standard solutions or filtered whey samples were placed in 1-mL plastic vials and analyzed in duplicate.

\section{Electrophoretic Conditions}

Separations were carried out using an $\mathrm{HP}^{3 \mathrm{D}}$ capillary electrophoresis system (Hewlett-Packard, Wilmington, $\mathrm{DE}) . \beta$-Lactoglobulin $\mathrm{A}$ or $\mathrm{B}$ variants were separated in an uncoated fused capillary column of $50 \mu \mathrm{m} \times 72$ cm PT-Polymicro Technologies, Phoenix, AZ and maintained at $40^{\circ} \mathrm{C}$ using $0.05 \mathrm{M}$ borate buffer containing $0.1 \%$ Tween 20 at $\mathrm{pH} 8.0$ by applying $25 \mathrm{kV}$. Sample injection was accomplished by using $5.1 \times 10^{5} \mathrm{~Pa}$ for 10 $\mathrm{s}$, and detection took place at $214 \mathrm{~nm}$.

\section{Rheological Measurements}

The rheological properties of the rennet-coagulated milk systems were investigated using a strain-controlled rheometer (RFSII fluids spectrometer; Rheometrics, Piscataway, NJ), fitted with a cone plate (cone angle: $0.0397 \mathrm{rad}$; diameter: $50 \mathrm{~mm}$ ) and a circulating environmental system for temperature control. To prevent the samples from drying during the experiments, a glass ring of $\sim 60 \mathrm{~mm}$ was placed around the measuring geometry, and the annulus was filled with silicone oil of low viscosity. The evolution of the renneting process was monitored by measuring the storage $\left[\mathrm{G}^{\prime}(t)\right]$ and loss $\left[\mathrm{G}^{\prime \prime}(t)\right]$ moduli at $32^{\circ} \mathrm{C}(\omega=6.0 \mathrm{rad} / \mathrm{s})$, recorded at strain values $(\gamma)$ of $7 \%$ over a period of up to $240 \mathrm{~min}$. Once this time had elapsed, frequency and strain sweeps were recorded.

\section{Statistical Analysis}

All experiments were performed in duplicate. An ANOVA was applied to determine the effects of $\beta$-LG variants and whey protein added to milk on coagulation properties of the model systems. Means were tested by Tukey's pairwise comparisons at a 95\% confidence level.

\section{RESULTS}

This study aimed to investigate the rennet-induced coagulation behavior of mixtures of skim milk powder with $\beta$-LG A and $\beta$-LG B whey protein variants in isolation and with a physical mixture of both ( $\beta$-LG A-B) in the presence of $\alpha$-LG A at a fixed $\beta$-LG: $\alpha$-LA ratio. Hence, it was of great interest to study in detail the nature of the possible interactions in the system that may have occurred between whey protein and $\mathrm{CN}$ micelles prior to the renneting process. To this end, capillary electrophoresis was used to probe the variations in the amount of native $\beta$-LG A and $\beta$-LG B that remained free after $\mathrm{CN}$ precipitation, prior to and after pasteurization treatment and as a function of the level of addition. Skim milk powder and the whey protein isolate powders were dissolved and the model skim milk 

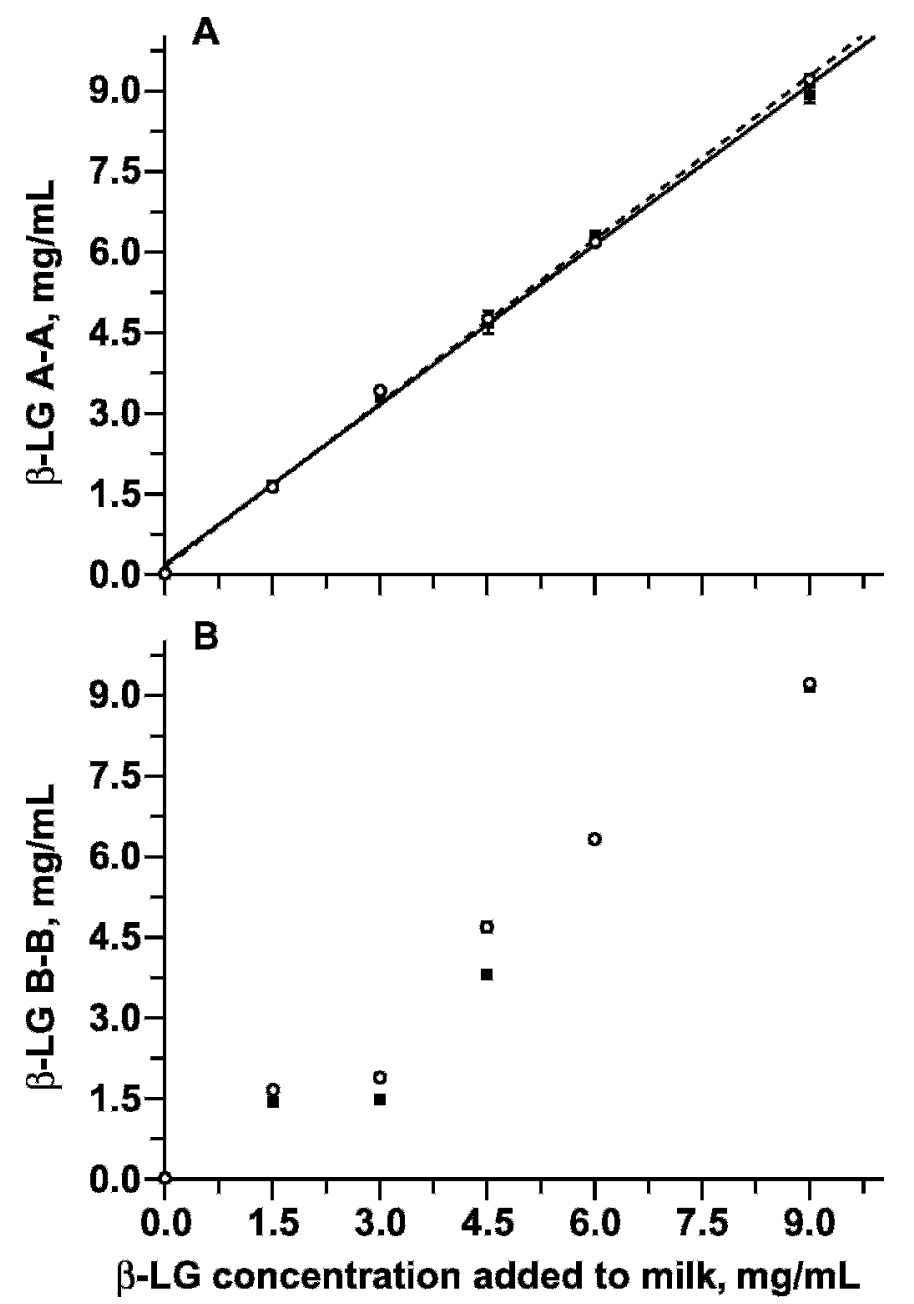

Figure 1. Variation in the measured concentration of $\beta$-LG after $\mathrm{CN}$ precipitation as a function of the amount of $\beta$-LG added prior to $(\bigcirc)$ and after $(\square)$ heat treatment $\left(65^{\circ} \mathrm{C}\right.$ for $\left.30 \mathrm{~min}\right)$. (A) $\beta$-Lactoglobulin A-A and (B) $\beta$-LG B-B. Dotted (unheated samples) and solid (heated samples) lines correspond to best-fit linear regression curves.

solutions were subjected to a pasteurization treatment and thereafter to renneting. In this way, it was possible to infer the amount of $\beta$-LG attached to the $\mathrm{CN}$ micelle before and after heat treatment. Figure 1 illustrates the dependence of the amount of free $\beta$-LG measured in these systems on the level of added protein. Figure $1 \mathrm{~A}$ shows the dependence of the amount of $\beta$-LG A in heated and unheated samples on the level of added protein. It shows that the increase in the level of $\beta$-LG A added was accompanied by a concomitant progressive increase observed in the amount of protein. This dependence was easily adjusted using a linear regression model (lines shown). A slope of $\sim 1.00$ was taken as the main evidence that $\beta$-LG A was not interacting at all with the rest of the proteins in the system; hence, it remained completely free for detection by capillary elec- trophoresis. It was also very interesting to note that no significant differences $(P \geq 0.05)$ were observed between the slopes of the regression lines of the untreated and heated milk samples, indicating that heating at $65^{\circ} \mathrm{C}$ for $30 \mathrm{~min}$ did not alter the behavior of $\beta$-LG A. This is consistent with previous studies that firmly demonstrated that $\beta$-LG A is stable to heat treatment (McLean et al., 1987; Manderson et al., 1998).

Figure 1B shows the corresponding results for the $\beta$ LG B variant. One can see that 2 domains of behavior were observed (i.e., addition of $\beta$-LG B up to $3.0 \mathrm{mg} /$ $\mathrm{mL}$ revealed only a marginal increase in the amount of $\beta$-LG B protein observed in the serum). This was replaced by a progressive increase in the detected concentration of $\beta$-LG B whey protein at levels equal to or greater than $\sim 4.5 \mathrm{mg} / \mathrm{mL}$, beyond which the dependence seemed to follow a linear tendency. In these mixtures, it was also interesting that no significant differences $(P$ $\geq 0.05$ ) in the amount of $\beta$-LG B were observed between heated and unheated samples. This behavior is consistent with the notion that $\beta$-LG B associates with CN up to an optimal (stoichiometric) ratio, beyond which surplus unbound whey protein remains free. Also, heat treatment did not seem to have brought about an effect on the amount of bound protein in these systems, because no differences were observed between thermally treated and untreated samples.

Figure 2 illustrates the change of the concentration of the individual whey proteins in the mixture $\beta$-LG AB [i.e., for $\beta$-LG A (Figure 2A) and $\beta$-LG B (Figure 2B) heated and unheated samples] as a function of added protein. In the case of $\beta$-LG A, similar slopes were found for the linear regression curves, and both sets of data (for heated and unheated samples) showed no significant differences $(P \geq 0.05)$ between them. Again, slopes of $\sim 1.00$ for both regression curves were taken as evidence that neither was there an interaction between $\beta$ LG $\mathrm{A}$ and the rest of the proteins in the system nor was it induced by heat treatment, in good agreement with the results obtained in the systems in which $\beta$-LG A was studied in isolation (Figure 2A). In turn, $\beta$-LG B proteins, when studied in the presence of $\beta$-LG A, generally showed lower concentrations of the observed amount of protein with respect to the total amounts added. This was confirmed by the low values for the slopes of the regression lines fitted to the full set of data. Also, 2 domains of behavior were noticed in these systems. At low concentrations and up to $\sim 1.5 \mathrm{mg} / \mathrm{mL}$, the whey proteins somehow seemed to become associated so that only a small concentration was detected and there was only a marginal dependence between the concentrations of observed vs. added whey protein. However, at concentrations greater than $\sim 2.25 \mathrm{mg} / \mathrm{mL}$, an increase was seen in the magnitude of this depen- 

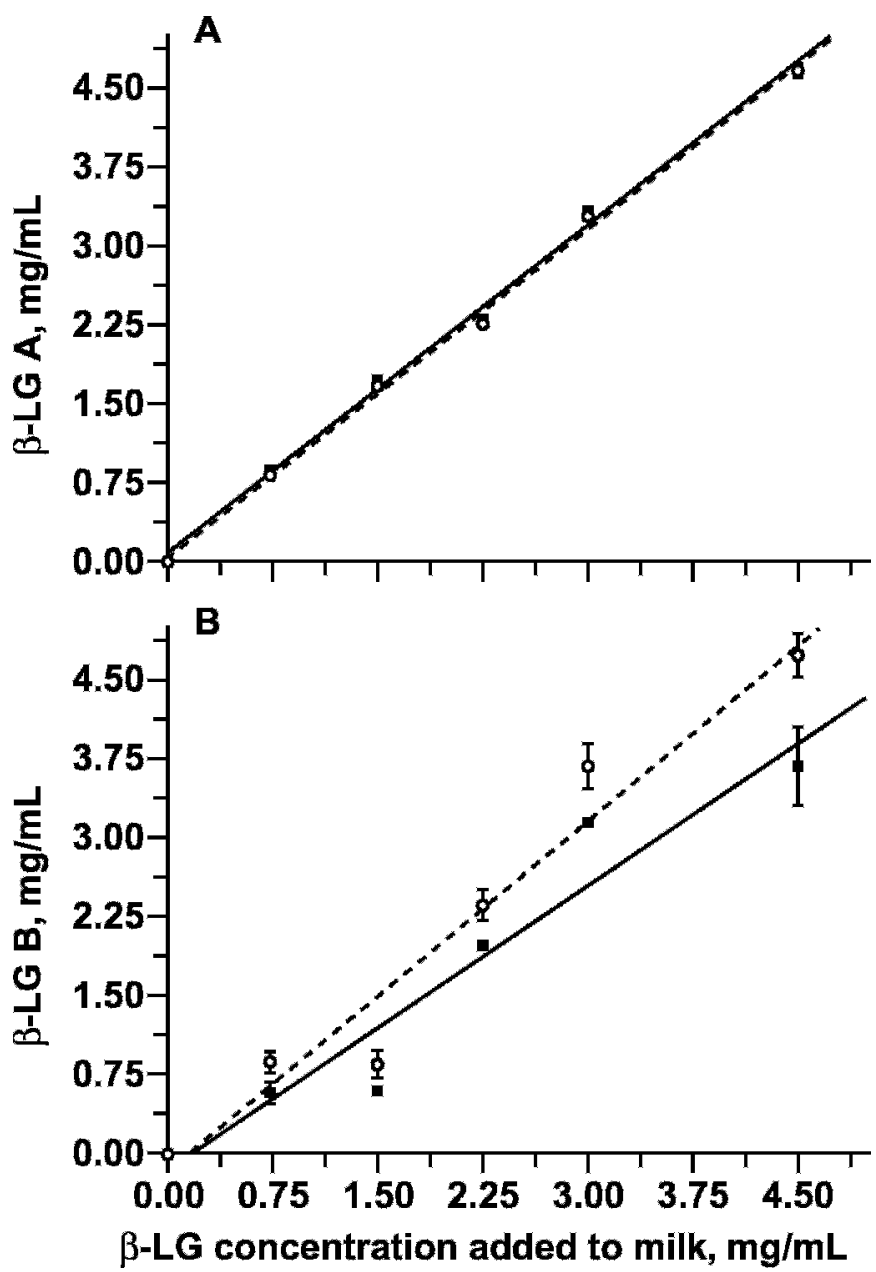

Figure 2. Variation in the concentration of $\beta$-LG after $\mathrm{CN}$ precipitation as a function of the amount of $\beta$-LG added prior to $(O)$ and after (ם) heat treatment $\left(65^{\circ} \mathrm{C}\right.$ for $\left.30 \mathrm{~min}\right)$. (A) $\beta$-Lactoglobulin $\mathrm{A}$ in phenotype A-B and (B) $\beta$-LG B in phenotype A-B. Dotted (unheated samples) and solid (heated samples) lines correspond to best-fit linear regression curves.

dence, consistent with the behavior observed for $\beta$-LG $\mathrm{B}$ in isolation.

Figure 3 shows the evolution of the storage modulus $\left(G^{\prime}\right)$ during the renneting process of skim milk in the presence of varying concentrations of $\beta$-LG A (Figure 1A), $\beta$-LG B (Figure 3B), $\beta$-LG A-B (Figure 3C), and a fixed amount of $\alpha$-LA. The 3 plots show that the $\mathrm{G}^{\prime}$ traces invariably showed an abrupt increase in their values within $\sim 1,000 \mathrm{~s}$ after the beginning of the enzymatic renneting reaction, followed by a monotonic exponential increase until a steady phase was attained by $10,000 \mathrm{~s}$. This behavior is characteristic of a gelling process under kinetic control. Inspection of the individual traces revealed that the addition of $\beta$-LG prior to heating and renneting led to an overall increase in the $\mathrm{G}^{\prime}$ values of all gel clot systems. Almost an order of

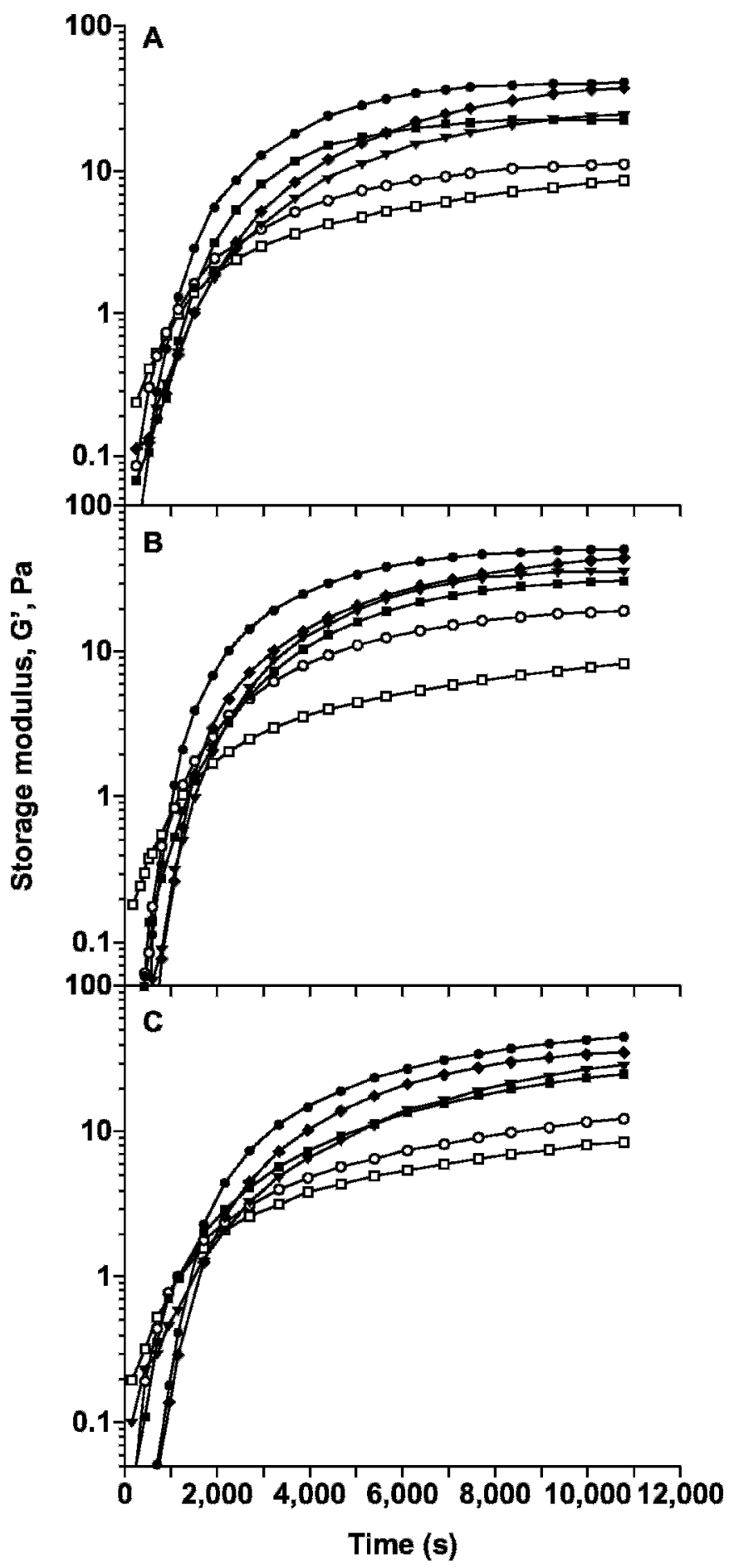

Figure 3. Evolution of the storage modulus $(\omega=6 \mathrm{rad} / \mathrm{s} ; \gamma=7 \%$; $32^{\circ} \mathrm{C}$ ), $\mathrm{G}^{\prime}$, as a function of time for rennet-induced heated skim milk (HSM) gels with added (A) $\beta$-LG A, (B) $\beta$-LG B, and (C) $\beta$-LG A-B. Symbol key: $(\square)$ HSM; (O) HSM $+0.225 \%$ whey protein; $(\square)$ HSM + $0.45 \%$ whey protein; $(\boldsymbol{\nabla}) \mathrm{HSM}+0.675 \%$ whey protein; $(\diamond) \mathrm{HSM}+$ $0.90 \%$ whey protein; $(\bullet)$ HSM $+1.35 \%$ whey protein. 
magnitude difference between gels with no whey protein added and those with the greater concentration $(1.35 \%)$ was observed in the 3 cases. A closer comparison of the 3 plots showed that gel clots containing the $\beta$-LG $\mathrm{B}$ variant experienced slightly greater final $\mathrm{G}^{\prime}$ values than those of $\beta$-LG A and $\beta$-LG A-B for the same concentration of added whey protein, as shown below. These results agree with those observed in acid-induced gels (Bikker et al., 2000), in which addition of $\beta$-LG B or $\beta$-LG $\mathrm{C}$ resulted in overall firmer gels than those with added $\beta$-LG A. Typical viscoelastic gel networks are formed as a result of the rennet coagulation process, as was evidenced by the typical mechanical spectra recorded at the end of the gelling process (results not shown).

The effect on the final $\mathrm{G}^{\prime}$ values (at $\omega=6.0 \mathrm{rad} / \mathrm{s}$ ) of the gels of adding increasing levels of the $3 \beta$-LG whey protein variants to skim milk is illustrated in Figure 4. This was investigated at $32^{\circ} \mathrm{C}$, the temperature at which the coagulation process was monitored (Figure $4 \mathrm{~A}$ ), and also after the gels were cooled to $10^{\circ} \mathrm{C}$ (Figure $4 \mathrm{~B})$. One can clearly observe that at both temperatures, addition of increasing levels of whey protein led to a progressive elevation of $G^{\prime}$ values of the gels obtained. At $32^{\circ} \mathrm{C}, \mathrm{G}^{\prime}$ of the gels containing $\beta$-LG B lay above those containing the $\beta$-LG A or $\beta$-LG A-B mixture, whereas at $10^{\circ} \mathrm{C}$, the $\mathrm{G}^{\prime}$ values of gels with added $\beta$-LG A-B and those with added $\beta$-LG $\mathrm{B}$ seemed to increase more steeply with the concentration of added whey protein variant than gels with added $\beta$-LG A. In general, the gels were firmer at 10 than at $32^{\circ} \mathrm{C}$ at similar concentrations of added protein. Also, at $10^{\circ} \mathrm{C}$ the shape of the curves was closer to sigmoidal and a clear change in dependence was observed at 0.675 and $0.900 \%$ added whey protein, respectively, for $\beta$-LG B and $\beta$-LG A. In the case of the loss modulus, G" (Figure $4 \mathrm{C}$ and $4 \mathrm{D}$ ), the variation in the moduli with the concentration of added whey protein essentially followed a trend similar to that of $\mathrm{G}^{\prime}$ values at 32 and $10^{\circ} \mathrm{C}$, respectively.

To gain a further understanding of the mechanisms and phenomena underlying the behavior of the system, the final values of $\tan \delta\left(=\mathrm{G}^{\prime \prime} / \mathrm{G}^{\prime}\right)$ were plotted as a function of the concentrations of added $\beta$-LG whey protein variants (Figure 5). The loss tangent is a very informative parameter that accounts for the overall viscoelastic properties of a given system, and it has been successfully used as a probe that is sensitive to the nature of bonds and to the relative contributions of different types of bonds and macromolecular interactions in milk (van Vliet and Walstra, 1985; Roefs, 1986; Walstra and van Vliet, 1986) and in polysaccharide gel systems (Goycoolea et al., 1995, 2000). At $32^{\circ} \mathrm{C}$ (Figure $5 \mathrm{~A}), \tan \delta$ values of the gels containing $\beta$-LG A showed a drastic increase $(P \leq 0.05)$ at $0.225 \%$ of added whey protein. This increase was followed by a gradual decrease until no further change in $\tan \delta$ was observed beyond $0.675 \%$. In the case of $\beta$-LG B, the gel network seemed to be slightly weakened (i.e., an increase in tan $\delta$ ) at a concentration of $0.45 \%$, whereas for $\beta$-LG A-B this was observed at $0.675 \%$. No significant differences $(P \geq 0.05)$ in $\tan \delta$ were observed among gels under the 3 types of treatment at whey protein levels of $\geq 0.900 \%$. Once the systems were cooled to $10^{\circ} \mathrm{C}$ (Figure 5B), the maximum $\tan \delta$ with addition of $\beta$-LG A shifted to $0.45 \%$ and it attained a value of $\sim 0.41$, which was significantly $(P \leq 0.05)$ higher than those for $\beta$-LG B or $\beta$-LG A-B. Although the increase in $\tan \delta$ values for $\beta$-LG B persisted at $0.45 \%$ of added protein with no further change beyond this concentration. In the case of $\beta$-LG A-B, essentially the same trend observed at $32^{\circ} \mathrm{C}$ was observed at $10^{\circ} \mathrm{C}$, and these values remained consistently lower than those for $\beta$-LG A and $\beta$-LG B, thus effectively reflecting a synergistic effect.

Measurement of the rennet coagulation time, considered here to be equivalent to the critical gel time and its dependence on the composition of the addressed systems, was yet another key piece of information derived from the dynamic rheology experiments, in agreement with previous studies that have used the same approach (Lucey et al., 2000; Esteves et al., 2001, 2002; Lucey, 2002). A number of methods based on mechanical properties have been proposed to determine the critical gelation point for chemically and physically cross-linked gel network systems (Tung and Dynes, 1982; Winter and Chambon, 1986; Djabourov, 1991). The criterion adopted in the present study to mark the onset of incipient formation of the gel network or the percolation threshold (i.e., where the system is assumed to have formed the first cluster of infinite molecular mass), that is, the rheological critical gel time $\left(t_{g e l}\right)$ was given by the time of crossover of $\mathrm{G}^{\prime}$ and $\mathrm{G}^{\prime \prime}$ (Tung and Dynes, 1982). Critical gel times calculated under this condition in polymer gels are known to be dependent on frequency, as demonstrated in the rigorous theoretical argument by Winter and Chambon (1986). However, in many instances neither is the application of the Winter-Chambon criterion experimentally feasible, nor can rheological measurements at the critical gel point be guaranteed to be at the linear viscoelastic region. Hence, $t_{g e l}$ was identified with the instant of the incipient prevalence of $\mathrm{G}^{\prime}$ over $\mathrm{G}^{\prime \prime}$ (i.e., when $\tan \delta$ became just less than 1.00; Tung and Dynes, 1982). This empirical approach has been applied to $\beta$-LG (Stading and Hermansson, 1990) and polysaccharide gels such as pectincalcium (Durand et al., 1990) and hydrophobically modified chitosan (Félix et al., 2005) systems.

Using the aforementioned approach to determine the critical gel time or rennet time, $t_{g e l}$, it was possible to 

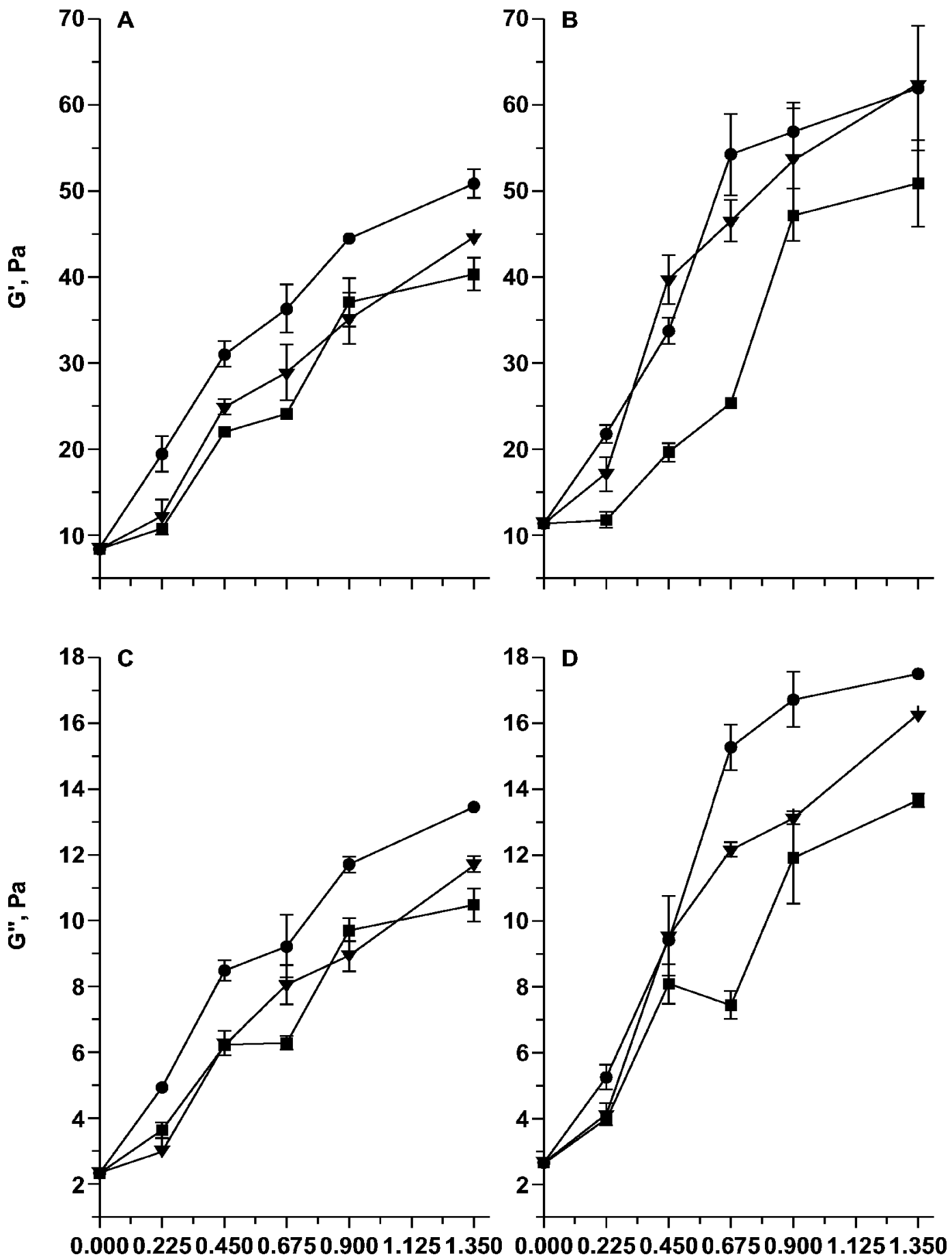

Protein added to milk, \%

Figure 4. Variation in the final storage, $G^{\prime}$, and loss, $G^{\prime \prime}$, moduli as a function of whey protein concentration for rennet-induced heated skim milk (HSM) gels with added whey protein variants $(\omega=6 \mathrm{rad} / \mathrm{s} ; \gamma=7 \%)$. Final storage modulus, $\mathrm{G}^{\prime}$, at $(\mathrm{A}) 32^{\circ} \mathrm{C}$ and $(\mathrm{B}) 10^{\circ} \mathrm{C}$; final

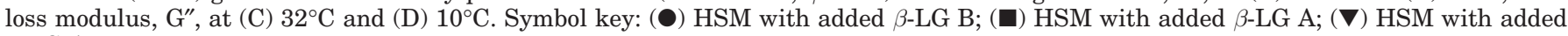
$\beta$-LG A-B. 


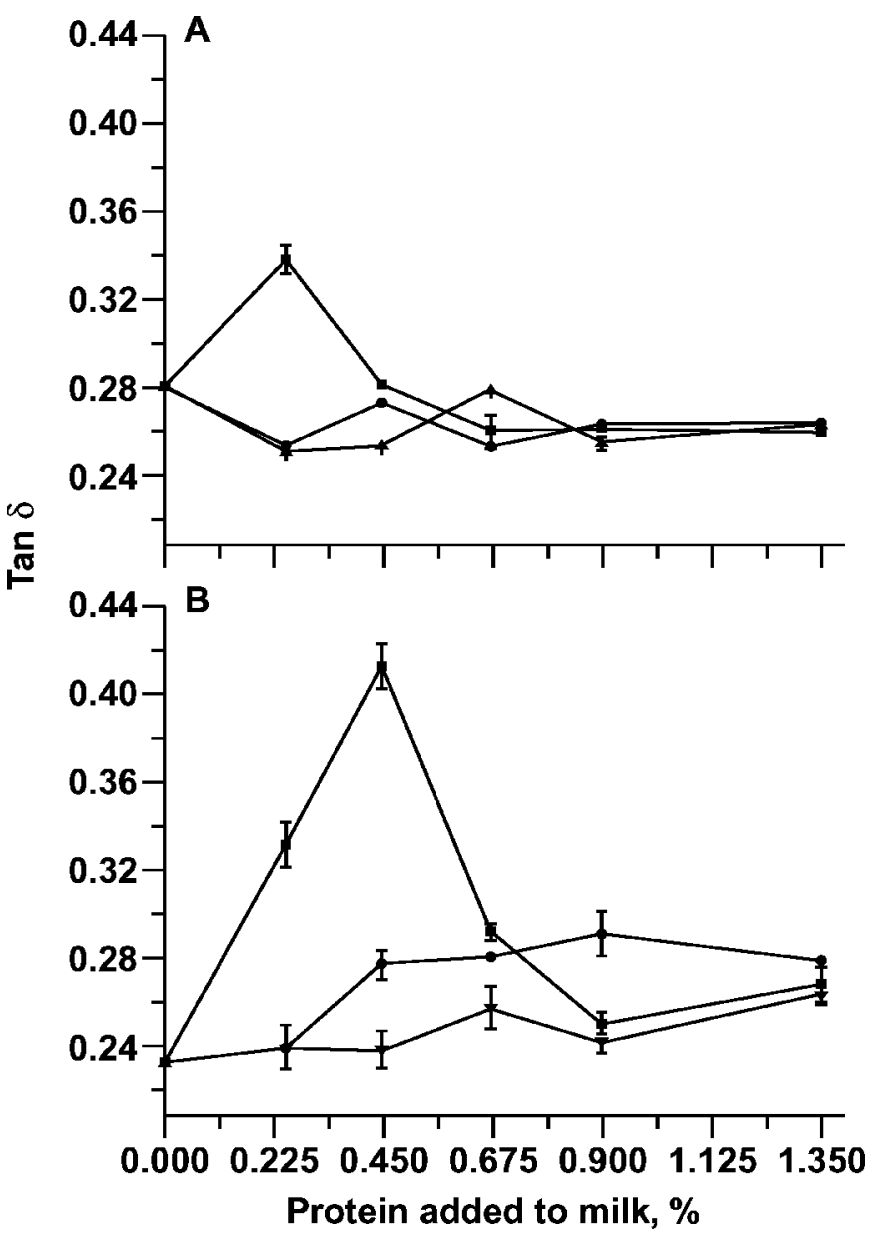

Figure 5. Variation in the final loss tangent, $\tan \delta$, as a function of whey protein concentration for rennet-induced heated skim milk (HSM) gels added with whey protein variants $(\omega=6 \mathrm{rad} / \mathrm{s} ; \gamma=7 \%$; $\left.32^{\circ} \mathrm{C}\right)$ at (A) $32^{\circ} \mathrm{C}$ and $(B) 10^{\circ} \mathrm{C}$. Symbol key: (ם) HSM with added $\beta$-LG A; $(\bullet)$ HSM with added $\beta$-LG B; ( $)$ HSM with added $\beta$-LG A-B.

study the kinetics of the system in terms of the variation of $t_{\text {gel }}$ with concentration of each added whey protein. Figure 6 shows that addition of $\beta$-LG A or $\beta$-LG B caused an initial reduction in $t_{\text {gel }}$ that reached a minimum at 0.450 and $0.675 \%$, respectively. This reduction was then followed by an increase in $t_{\text {gel }}$ up to a whey protein concentration of $0.90 \%$, describing a "U-shaped" curve, and afterward by a new decrease at the highest level of added whey protein (1.35\%), and both gels assumed identical $t_{g e l}$ values. In the case of $\beta$-LG A-B, the initial reduction and sudden increase in $t_{\text {gel }}$ at $0.9 \%$ whey protein was even more pronounced, whereas the magnitude of the last decrease was still lower than that of $\beta$ LG A or $\beta$-LG B. This result argued in favor of a possible synergistic effect for both whey protein variants when they were together, as in the mixture $\beta$-LG A-B. The increase in $t_{\text {gel }}$ at $0.9 \%$ of whey protein either in isolation or in the mixture, coincided with the convergence in

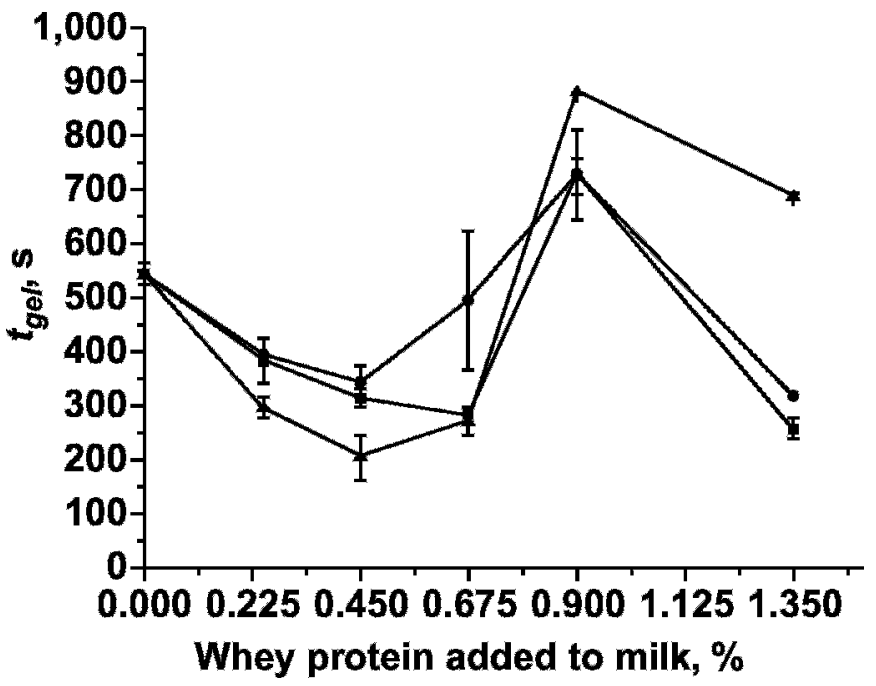

Figure 6. Critical gel time $\left(t_{\text {gel }}\right)$ of rennet-induced heated skim milk (HSM) gels as a function of whey protein concentration $(\omega=6$ $\mathrm{rad} / \mathrm{s} ; \gamma=7 \% ; 32^{\circ} \mathrm{C}$ ). Symbol key: (ם) HSM with added $\beta$-LG A; $(\bullet)$ HSM with added $\beta$-LG B; ( $)$ HSM with added $\beta$-LG A-B.

the minima in $\tan \delta$ values registered at $32^{\circ} \mathrm{C}$ and after $10,800 \mathrm{~s}$ (Figure 6) of reaction, suggesting that above a certain concentration of added whey protein, the behavior of the systems was not specific to the type of whey protein added. The $t_{g e l}$ is bound to be determined not only by the kinetics of the gelling process itself but also by the kinetics of the enzymatic reaction, before and up to the percolation point. The observed differences in $t_{g e l}$ associated with the type and concentration of whey protein suggest that the interactions mediating between these and $\mathrm{CN}$ proteins vary in their extent, and perhaps also in their specificity.

\section{DISCUSSION}

Gelation of milk during the renneting process can be conceived of as the consequence of a series of complex assembling phenomena that lead to the formation of bonds between $\mathrm{CN}$ aggregates and to their subsequent rearrangement (Walstra and van Vliet, 1986). Altogether, these processes lead to the setup of a 3-dimensional gel network. In this study, a reconstituted model milk system was formulated using $\beta$-LG whey protein variants and skim milk powder (Lucey et al., 1993). After being subjected to heat treatment prior to renneting, the protein species in the mixtures can be conceived of as existing in any of the following states: 1) $\mathrm{CN}$ micelles coexisting with free unaggregated whey proteins; 2) CN micelles coexisting with free aggregated whey proteins; 3) CN micelles with whey protein species grafted to their surface, or 4) a combination of states 1 and 3 . 
Results of the capillary electrophoresis experiments in mixtures with added $\beta$-LG A allowed us to infer almost unequivocally that this variant does not associate with the CN micelles before renneting (Figure 1), regardless of the heat treatment. Hence, one can assume that in this case, the proteins agree with state 1 above. By contrast, the capillary electrophoresis results for mixtures with added $\beta$-LG B seem to reveal that a fraction of whey protein associates with the $\mathrm{CN}$ micelle up to $\sim 0.3 \mathrm{mg} / \mathrm{mL}$. For $\beta$-LG A, the interaction between the $\mathrm{CN}$ and whey protein species is not affected by moderate heat treatment $\left(65^{\circ} \mathrm{C}\right.$ for $\left.30 \mathrm{~min}\right)$, consistent with the suggestion of $\mathrm{CN}$ micelles with $\beta$-LG B species grafted to their surface (state 3 above) up to $\sim 0.3 \mathrm{mg} /$ $\mathrm{mL}$. Beyond this concentration, surplus whey protein is expected to remain in a free state (state 1). The lower charge density of $\beta$-LG B species, compared with $\alpha$-LG A species, may account for the ease of the former in associating with the $\mathrm{CN}$ micelle surface, as a result of the lower electrostatic repulsion expected.

A number of studies have addressed the association phenomena between $\beta$-LG and $\kappa$-CN in milk in greater depth (Noh et al., 1989b; Law et al., 1994), both in a model micelle system (Noh et al., 1989a; Reddy and Kinsella, 1990) and in solutions containing pure $\beta$-LG and $\kappa$-CN (McKenzie et al., 1971; Euber and Brunner, 1982), with emphasis on the role of heating and denaturation in the behavior of both types of protein species (de Wit and Swinkels, 1980; Corredig and Dalgleish, 1996; Oldfield et al., 1998). In contrast with previous studies, the evidence gathered by capillary electrophoresis in the present study demonstrates that moderate heating $\left(65^{\circ} \mathrm{C}, 30 \mathrm{~min}\right)$ itself does not significantly affect the association behavior of $\beta$-LG with $\mathrm{CN}$ in colloidal solutions.

The results of this study show that both the viscoelastic mechanical properties at equilibrium and the kinetics of rennet-coagulated gels of reconstituted skim milk are greatly affected by the type and level of addition of $\beta$-LG A and $\beta$-LG B whey proteins, either when added in isolation or when mixed, as in $\beta$-LG A-B (Figure 3). Indeed, the progressive increase in the level of addition of $\beta$-LG $\mathrm{B}, \beta$-LG A, and $\beta$-LG A-B clearly leads to a concomitant elevation in the final viscoelastic $G^{\prime}$ values of the formed clot, as shown in Figure 3. In this regard, it is firmly accepted in polymer gels that the viscoelastic $\mathrm{G}^{\prime}$ modulus is directly proportional to the number of elastically effective bonds or to the overall degree of connectivity within a defined unit volume of the structure building up the gel network (Ferry, 1980). Rennet milk gels, although basically composed of CN macromolecules, differ from proper "polymer gels," in that they are modeled as particle gel systems (Horne, 1999). Their elasticity is therefore based on the type and ex- tent of interactions between the constituent particles. The fact that addition of $\beta$-LG $\mathrm{B}$ resulted in stronger gels than those with added $\beta$-LG A is also consistent with differences in the overall electrical charge density of $A$ and $B$ variants, which seems to mediate the extent they associate with, or modify the aggregation of, rennet hydrolysis products (i.e., hydrophobic para- $\kappa$-CN and hydrophilic glycomacropeptides; Mercier et al., 1973).

An increase in the size of the $\mathrm{CN}$ micelle as a result of the association with $\beta$-LG has also been demonstrated in independent studies (Noh et al., 1989a,b; Fairise et al., 1999) and would also account for a greater volume fraction, and hence for a closer packing, for the same polymer concentration. This will therefore lead to a closer proximity of reactive sites at the reacting species and hence to a firmer gel network, as previously suggested (Waungua et al., 1996). Particle size determinations using photo correlation spectroscopy to support this hypothesis would have been extremely informative. However, access to this technique was not available in our laboratories during the course of this study. By contrast, the fact that $\beta$-LG A also affected the mechanical strength of the rennet-induced gels, and yet that this variant did not seem to bind to the $\mathrm{CN}$ micelle surface prior to renneting, suggests that an increase in micelle particle size is by no means the only explanation to account for the observed effects. Other species, such as the rennet hydrolysis products, may surely play a very important role in determining the extent and type of interactions governing the connectivity in the gel network.

In previous studies in acid-induced gels, Bikker et al. (2000) showed a preferential effect for $\beta$-LG B over $\beta$-LG A to elevate $\mathrm{G}^{\prime}$ values with the concomitant increase in concentration. Manderson et al. (1998) suggested that $\beta$-LG A tends to form a greater proportion of lower molecular weight aggregates during the heating of milk, compared with other variants.

The fact that greater $G^{\prime}$ values were attained by the rennet-induced gels after cooling from 32 to $10^{\circ} \mathrm{C}$, once they were originally formed (at $32^{\circ} \mathrm{C}$ ), seems to indicate that the nature of the bonds ultimately building up the gel network structure is not essentially hydrophobic. In that case, we would have expected the clots to have greater mechanical strength at higher temperatures (Haque and Morris, 1993; Sarkar, 1995; Desbriéres et al., 2000) than at lower temperatures. This was in contrast to what was observed experimentally, which was in agreement with the behavior of many polysaccharide and protein biopolymer gels (Richardson and Ross-Murphy, 1981).

The results for the variations in $\tan \delta$ as a function of added whey protein concentration at the end of gelation at either 32 or $10^{\circ} \mathrm{C}$ allowed us to gain an even 
better understanding of the behavior of the system. Addition of the whey protein variants $\beta$-LG A and $\beta$ LG B differently affected the viscoelastic properties of the $\mathrm{CN}$ gels at equilibrium (after $\sim 10,800 \mathrm{~s}$ ). An increase in $\tan \delta$ values at low whey protein concentrations of 0.225 and $0.450 \%$ at 32 and $10^{\circ} \mathrm{C}$, respectively, observed particularly for clots with added $\beta$-LGA, argues in favor of a highly specific effect that operates under a narrow range of concentrations for this variant. In previous studies in acid-induced gels from heated milk (Lucey et al., 1997) and in milk gel systems with concomitant actions of coagulant and acid, increases in $\tan \delta$ with time during the course of gelation were ascribed to the loss of colloidal calcium phosphate from micelles already part of the gel network (Lucey et al., 2000). However, in more recent work, Esteves et al. (2003) suggested that increases in $\tan \delta$ values for gels coagulated with plant coagulants and chymosin were due to fast rearrangements in the gel network structure. At present, we are not aware of studies that have specifically addressed the effect of the addition of whey protein variants on the viscoelastic properties of rennet-induced gels. At this stage, we do not have sufficient experimental evidence showing unequivocally that either of these mechanisms could account for the observed effects of $\beta$-LG A on tan $\delta$. Moreover, comparison of the $\tan \delta$ values at $32^{\circ} \mathrm{C}$ with those of the gels once they cooled to $10^{\circ} \mathrm{C}$ at this low range of concentrations revealed an even greater increase in $\tan \delta$ for gels with added $\beta$-LG A. This effect may be related to an increase in $\mathrm{G}^{\prime \prime}$ in the cooled gels (Figure 4C and 4D) effected by the increase in the viscosity of the sol fraction because of the increase in greater local concentration of whey protein that remains unbound in the sol fraction. At even greater concentrations of added $\beta$-LG $\mathrm{A}, \tan \delta$ values tend to decrease under a monotonic trend at both temperatures as a consequence of the progressive increase in $\mathrm{G}^{\prime}$ (Figures 3A and 3B). By contrast, the addition of $\beta$-LG B has a very different effect on $\tan \delta$ at either 32 or $10^{\circ} \mathrm{C}$ than does the addition of $\beta$-LG A. At $32^{\circ} \mathrm{C}$, only a marginal decrease in $\tan \delta$ was observed, even at the lowest concentration of whey protein, and almost no dependence was seen at greater levels of addition. One can observe that at $10^{\circ} \mathrm{C}$, after no change in $\tan \delta$ at $0.225 \%$ of added whey protein, addition at $0.45 \%$ caused a slight increase in $\tan \delta$, with little further change at greater concentrations. This may be the result of both the increase in the concentration of surplus $\beta$-LG $\mathrm{B}$ in the sol fraction and the formation of aggregates of greater molecular weight than those of $\beta$-LG A (Manderson et al., 1998).

The other important issue addressed in this study was the effect of the addition of whey protein variants on the kinetics of gel formation of rennet-induced gels.
The variation in the critical gel time, $t_{\text {gel }}$, with the concentration of whey protein (Figure 6) revealed that 3 domains of behavior seem to operate in these systems, each governed by somewhat distinct predominant phenomena. These 3 domains are observed in $\beta$-LG A, $\beta$ LG B, and $\beta$-LG A-B. Specifically, at low whey protein concentrations ( 0 to $0.675 \%$ ), the reduction in $t_{\text {gel }}$ with increasing amounts of added whey protein can be explained as the consequence of an increase in the rate of aggregation of renneted CN micelles, which could account for a reduction in the time to achieve gel percolation. Differences in $t_{\text {gel }}$ at around $\sim 0.3 \%$ of whey proteins were negligible among mixtures with added $\beta$-LG variant $\mathrm{A}$ or $\mathrm{B}$. These results are in agreement with the notion that milk renneting clotting times do not differ regardless of whether $\beta$-LG is type $\mathrm{A}$ or $\mathrm{B}$ (Aaltonen and Antila, 1987; Pagnacco and Caroli, 1987; Lodes et al., 1996; Celik, 2003).

In line with this interpretation, the association of whey proteins with CN micelles, rennet hydrolysis products, or both is likely to proceed up to a point, beyond which the system surface becomes saturated with whey protein. Hence, at concentrations $>0.6 \%$, surplus whey protein may start to form aggregates that may either impose steric restrictions on access of the enzyme to the reactive sites of the $\mathrm{CN}$ micelles or prevent their aggregation, as suggested previously (van Hooydonk et al., 1987). This could account for the large increase in $t_{\text {gel }}$ observed in the vicinity of $0.90 \%$ of added whey protein. In connection with this interpretation, Holt and Horne (1996) have suggested that $\beta$-LG aggregates, which are known to be stiff and rodlike (Griffen et al., 1993), must reptate through the surface $\kappa$-CN layer ("hairy layer") to react with disulfide bonds of $\mathrm{CN}$ in the micelles. Once attached to the $\mathrm{CN}$ micelle surface, such aggregates would protrude from the micelle surface as filamentous appendages, thus effectively providing steric effects that could limit further association of $\beta$-LG (Mohammad and Fox, 1987).

The further decrease in $t_{\text {gel }}$ seen at the greatest concentration of added whey protein can be explained as a consequence of a destabilization of $\mathrm{CN}$ because of the high concentration of whey proteins. Exclusion effects between whey proteins and $\mathrm{CN}$ micelles at such a high concentration cannot be ruled out either, because these will contribute to favoring the self-association of $\mathrm{CN}$ confined in its own phase.

It was very interesting to confirm that the interaction of $\beta$-LG B with the CN micelle, as probed by capillary electrophoresis, reached an optimum at a level of $\sim 0.30 \%$ of whey protein addition, a value that was also in agreement with some of the rheological parameters of the system, particularly with $t_{\text {gel }}$ and $\tan \delta$ measurements. This could indicate that the heterotypic associ- 
ated species between $\mathrm{CN}$ micelle and $\beta$-LG B whey protein, originally formed at room temperature, persisted after moderate heat treatment and renneting.

Even when only $\beta$-LG B was found to associate with $\mathrm{CN}$ prior to renneting, both $\beta$-LG $\mathrm{A}$ and $\beta$-LG $\mathrm{B}$, either alone or mixed, had a profound influence on the mechanical strength and coagulation kinetics of the rennet-induced CN gels. This knowledge is expected to be useful to exert better control and optimize processing conditions during cheese manufacturing.

\section{ACKNOWLEDGMENTS}

These studies were supported by the Mexican National Council of Science and Technology (CONACYT) research grant No. 42340. A scholarship to M. A. M. from the Programa de Mejoramiento del Profesorado (PROMEP) is also gratefully acknowledged.

\section{REFERENCES}

Aaltonen, M. L., and V. Antila. 1987. Milk renneting properties and the genetics variants of proteins. Milchwissenschaft 42:490-492.

Basch, J. J., and S. N. Timasheff. 1967. Hydrogen ion equilibria of the genetics variants of bovine $\beta$-lactoglobulin. Arch. Biochem. Biophys. 118:37-47.

Bewley, M. C., B. Y. Qin, G. B. Jameson, L. Sauwyer, and E. N. Baker. 1997. Bovine $\beta$-lactoglobulin and its variants: A threedimensional structural perspective. Pages 100-109 in Milk Protein Polymorphism. Special issue no. 9702. International Dairy Federation, Brussels, Belgium.

Bikker, J. F., S. G. Anema, Y. Li, and J. P. Hill. 2000. Rheological properties of acid gels prepared from heated milk fortified with whey protein mixture containing the $\mathrm{A}, \mathrm{B}$, and $\mathrm{C}$ variants of $\beta$ lactoglobulin. Int. Dairy J. 10:723-732.

Brittan, H., R. Lowe, G. E. Norris, T. M. Kitson, and J. P. Hill. 1997. Sodium dodecyl sulphate polyacrylamide gel electrophoresis of $\beta$-lactoglobulin variants, A, B and C. Relative mobilities of heated and unheated samples. Pages 212-216 in Milk Protein Polymorphism. Special issue no. 9702. International Dairy Federation, Brussels, Belgium.

Celik, S. 2003. $\beta$-Lactoglobulin genetic variants in Brown Swiss breed and its association with compositional properties and rennet clotting time of milk. Int. Dairy J. 13:727-731.

Choi, J. 1996. Effects of genetics variants of $\kappa$-casein and $\beta$-lactoglobulin and heat treatments on cheese yielding capacity, cheese composition and coagulation properties of milk. MS Thesis. McGill University, Ste. Anne-de-Bellevue, Québec, Canada.

Corredig, M., and D. G. Dalgleish. 1996. Effect of temperature and $\mathrm{pH}$ on the interactions of whey proteins with casein micelles in skim milk. Food. Res. Int. 29:49-55.

Creamer, L. K., and D. P. Harris. 1997. Relationship between milk protein polymorphism and physico-chemical properties. Pages 110-123 in Milk Protein Polymorphism. Special issue no. 9702. International Dairy Federation, Brussels, Belgium.

Dalgleish, D. G. 1990. The effect of denaturation of $\beta$-lactoglobulin on renneting: A quantitative study. Milchwissenschaft 45:491-494.

Desbriéres, J., M. Hirrien, and S. B. Ross-Murphy. 2000. Thermogelation of methylcellulose: Rheological considerations. Polymer 41:2451-2461.

de Wit, J. N., and G. A. M. Swinkels. 1980. A differential scanning calorimetric study of the thermal denaturation of bovine $\beta$-lactoglobulin. Biochim. Biophys. Acta 624:40-50.

Djabourov, M. 1991. Gelation-A review. Polym. Int. 25:135-143.

Durand, D., C. Bertrand, A. H. Clark, and A. Lips. 1990. Calciuminduced gelation of low methoxy pectin solutions-Thermody- namic and rheological considerations. Int. J. Biol. Macromol. 12:14-18.

Esteves, C. L. C., J. A. Lucey, and E. M. V. Pires. 2001. Mathematical modelling of the formation of rennet-induced gels by plant coagulants and chymosin. J. Dairy Res. 68:499-510.

Esteves, C. L. C., J. A. Lucey, and E. M. V. Pires. 2002. Rheological properties of milk gels made with coagulants of plant origin and chymosin. Int. Dairy J. 12:427-434.

Esteves, C. L. C., J. A. Lucey, T. Wang, and E. M. V. Pires. 2003. Effect of $\mathrm{pH}$ on the gelation properties of skim milk gels made from plant coagulants and chymosin. J. Dairy Sci. 86:2558-2567.

Euber, J. R., and J. R. Brunner. 1982. Interaction of $\kappa$-casein with inmobilized $\beta$-lactoglobulin. J. Dairy Sci. 65:2384-2387.

Euston, S. R., R. L. Hirts, and J. P. Hill. 1999. The emulsifying properties of $\beta$-lactoglobulin genetic variants $\mathrm{A}, \mathrm{B}$, and C. Colloids Surf. B: Biointerfaces 12:193-202.

Fairise, J.-F., P. Cayot, and D. Lorient. 1999. Characterisation of the protein composition of casein micelles after heating. Int. Dairy J. 9:249-254.

Félix, L., J. Hernández, W. M. Argüelles-Monal, and F. M. Goycoolea. 2005. Kinetics of gelation and thermal sensitivity of N-isobutyryl chitosan hydrogels. Biomacromolecules 6:2408-2415.

Ferry, J. D. 1980. Viscoelastic Properties of Polymers. 3rd ed. John Wiley \& Sons, New York, NY.

Goycoolea, F. M., M. Milas, and M. Rinaudo. 2000. Heterotypic interactions of deacetylated xanthan with a galactomannan of high galactose substitution during synergistic gelation. Pages 229240 in Gums and Stabilisers for the Food Industry 10. P. A. Williams and G. O. Phillips, ed. The Royal Society of Chemistry, Cambridge, UK.

Goycoolea, F. M., R. K. Richardson, E. R. Morris, and M. J. Gidley. 1995. Stoichiometry and conformation of xanthan in synergistic gelation with locust bean gum or konjac glucomannan. Macromolecules 28:8308-8320.

Griffen, W. G., M. C. A. Griffen, S. R. Martin, and J. Price. 1993. Molecular basis for thermal aggregation of bovine $\beta$-lactoglobulin A. J. Chem. Soc., Faraday Trans. 89:3395-3406.

Haque, A., and E. R. Morris. 1993. Thermogelation of methylcellulose. Part I: Molecular structures and processes. Carbohydr. Polym. 22:161-173.

Hill, J. P., M. J. Boland, L. K. Creamer, S. G. Anema, D. E. Other, G. R. Paterson, R. Lowe, R. L. Motion, and W. C. Thresher. 1996. The effect of bovine $\beta$-lactoglobulin phenotype on the properties of $\beta$-lactoglobulin milk composition and dairy products. Pages 281-294 in Macromolecular Interactions in Food Technology. American Chemical Society, Washington, DC.

Hill, J. P., W. C. Thresher, M. J. Boland, L. K. Creamer, S. G. Anema, G. Manderson, D. E. Other, G. R. Paterson, R. Lowe, R. G. Burr, R. L. Motion, A. Winkelman, and B. Wickham. 1997. The polymorphism of the milk protein $\beta$-lactoglobulin: A review. Pages 173 202 in Milk Composition Production and Biotechnology. R. S. A. Welch, D. J. W. Burns, S. R. Davis, A. J. Popay, and C. G. Prosser, ed. CAB International, New York, NY.

Holt, C., and D. S. Horne. 1996. The hairy casein micelle: Evolution of the concept and its implications for dairy technology. Neth. Milk Dairy J. 50:85-111.

Horne, D. S. 1999. Formation and structure of acidified milk gels. Int. Dairy J. 9:261-268.

Law, A. J. R., D. S. Horne, J. M. Banks, and J. Leaver. 1994. Heatinduced changes in the whey proteins and casein. Milchwissenschaft 49:125-129.

Lodes, A., J. Burchberger, I. Krause, J. Aumann, and H. Klostermeyer. 1996. The influence of genetic variants of milk proteins on the compositional and technological properties of milk. 2. Rennet coagulation time firmness of the rennet curd. Milchwissenschaft 51:543-547.

Lucey, J. A. 2002. Formation and physical properties of milk protein gels. J. Dairy Sci. 85:281-294.

Lucey, J. A., C. Gorry, and P. F. Fox. 1993. Rennet coagulation properties of heated milk. Agric. Sci. Finland 2:361-368. 
Lucey, J. A., M. Tamehana, H. Singh, and P. A. Munro. 2000. Rheological properties of milk gel formed by a combination of rennet and glucona- $\delta$-lactone. J. Dairy Res. 67:415-427.

Lucey, J. A., C. T. Teo, P. A. Munro, and H. Singh. 1997. Rheological properties at small (dynamic) and large (yield) deformations of acid gels made from heated milk. J. Dairy Res. 64:591-600.

Mailliart, P., and B. Ribadeau-Dumas. 1988. Preparation of $\beta$-lactoglobulin and $\beta$-lactoglobulin-Free proteins from whey rententate by $\mathrm{NaCl}$ salting out at low $\mathrm{pH}$. J. Food Sci. 53:743-745.

Manderson, G. A., M. J. Hardman, and L. K. Creamer. 1998. Effect of heat treatment on the conformation and aggregation of $\beta$-lactoglobulin A, B, and C. J. Agric. Food Chem. 46:5052-5061.

Marziali, A. S., and K. F. Ng-Kwai-Hang. 1986. Effects of milk composition and genetics polymorphism on cheese composition. J. Dairy Sci. 69:2533-2542.

McKenzie, G. H., R. S. Norton, and W. H. Sawyer. 1971. Heat-induced interaction of $\beta$-lactoglobulin and $\kappa$-casein. J. Dairy Res. 38:343-351.

McLean, D. M., E. R. B. Graham, R. W. Ponsoni, and H. A. McKenzie. 1987. Effects of milk protein genetic variants on and composition on heat stability of milk. J. Dairy Res. 54:219-235.

Mercier, J. C., G. Brignon, and B. Ribadeau-Dumas. 1973. Primary structure of bovine $\kappa$ B-casein. Complete sequence. Eur. J. Biochem. 35:222-235.

Mohammad, K. S., and P. F. Fox. 1987. Heat-induced microstructural changes in casein micelles before and after heat coagulation. $\mathrm{N}$. Z. J. Dairy Sci. 22:191-203.

Ng-Kwai-Hang, K. F. 1998. Genetic polymorphism of milk proteins: Relationships with production traits, milk composition and technological properties. Can. J. Anim. Sci. 78:131-147.

Noh, B., L. K. Creamer, and T. Richardson. 1989a. Thermally induced complex formation in an artificial milk system. J. Agric. Food Chem. 37:1395-1400.

Noh, B., T. Richardson, and L. K. Creamer. 1989b. Radiolabelling study of the heat induced interactions between $\alpha$-lactalbumin, $\beta$ lactoglobulin and $\kappa$-casein in milk and in the buffer solutions. J. Food Sci. 54:889-893.

Oldfield, D. J., H. Singh, and M. W. Taylor. 1998. Association of $\beta$ lactoglobulin and $\alpha$-lactalbumin with the casein micelles in skim milk heated in an ultra-high temperature plant. Int. Dairy J. 8:765-770.
Olguín-Arredondo, H., and B. Vallejo-Córdoba. 1999. Separation and determination of $\beta$-lactoglobulin variants $\mathrm{A}$ and $\mathrm{B}$ in cow's milk by capillary free zone electrophoresis. J. Capillary Electrophoresis Microchip Technol. 6:145-149.

Pagnacco, G., and A. Caroli. 1987. Effect of casein and $\beta$-Lg genotypes on renneting properties of milk. J. Dairy Res. 54:479-485.

Paterson, G. R., D. E. Otter, and J. P. Hill. 1995. Application of capillary electrophoresis in the identification of phenotypes containing the $\beta$-lactoglobulin C variant. J. Dairy Sci. 78:2637-2644

Reddy, I. M., and J. E. Kinsella. 1990. Interaction of $\beta$-lactoglobulin with $\kappa$-casein micelles as assessed by chymosin hydrolysis. Effects of added reagents. J. Agric. Food Chem. 38:311-318.

Richardson, R. K., and S. B. Ross-Murphy. 1981. Mechanical properties of globular protein gels: 1 . Incipient gelation behavior. Int J. Biol. Macromol. 3:315-322.

Roefs, S. P. F. M. 1986. Structure of acid casein gels. A study of gels formed after acidification in the cold. PhD Thesis. Wageningen Agricultural University, Wageningen, the Netherlands.

Sarkar, N. 1995. Kinetics of thermal gelation of methyl cellulose and hydroxypropyl methyl cellulose in aqueous solutions. Carbohydr. Polym. 26:195-203.

Stading, M., and A. M. Hermansson. 1990. Viscoelastic behavior of $\beta$-lactoglobulin gel structures. Food Hydrocoll. 4:121-135.

Tong, P. S., S. Vink, N. Y. Farkye, and J. F. Medrano. 1993. Effect of genetic variants of milk proteins on the yield of cheddar cheese. Pages 179-187 in Cheese Yield and Factors Affecting Its Control. International Dairy Federation, Cork, Ireland.

Tung, C. Y. M., and P. J. Dynes. 1982. Relationship between viscoelastic properties and gelation in thermosetting systems. J. Appl. Polyml. Sci. 27:569-574.

van Hooydonk, A. C. M., H. G. Hagedoom, and I. J. Boerrigter. 1987. The renneting properties of heated milk. Neth. Milk Dairy J. 41:3-18.

van Vliet, T., and P. Walstra. 1985. Note on the shear modulus of rennet-induced milk gels. Neth. Milk Dairy J. 39:115-118.

Walstra, P., and T. van Vliet. 1986. The physical chemistry of curd making. Neth. Milk Dairy J. 40:241-259.

Waungana, A., H. Singh, and R. J. Bennett. 1996. Influence of denaturation and aggregation of $\beta$-lactoglobulin on rennet coagulation properties of skim milk and ultrafiltered milk. Food Res. Int. 29:715-721.

Winter, H. H., and F. Chambon. 1986. Analysis of linear viscoelasticity of a crosslinking polymer at the gel point. J. Rheol. 30:367-382. 